\author{
Z.S. Kenzhebaeva ${ }^{1 *}$, A.Y. Toiganbayeva ${ }^{2}$ \\ ${ }^{1}$ University NARXOZ, Kazakhstan, Almaty \\ ${ }^{2}$ Kazakh Ablai Khan University of International Relations and World Languages, Kazakhstan, Almaty \\ *e-mail: zere.kenzhebaeva@narhoz.kz
}

\title{
DIGITAL ECONOMY AS A NEW THEORY OF DEVELOPMENT: CHALLENGES, OPPORTUNITIES AND PROSPECTS FOR DEVELOPMENT IN KAZAKHSTAN
}

The article discusses the concepts and directions of digitalization, digitalization of the economy and the penetration of digital processes into business, which are currently used in all areas,including especially in the economy. The transition from the traditional format of information exchange to an innovative digital one includes the goals and objectives of implementing digital processes in the economy, the most important of which are: improving the quality of life of the state's population, increasing the effectiveness and efficiency of business processes, maintaining the availability and security of information in the context of digitalization.

Currently, the state is implementing many programs aimed at digitalizing the national economy. In the course of work in this direction, it is necessary to specify the essence, goals and directions of digitalization of the digital economy. In order to effectively and quickly implement digitalization in the country, it is necessary, first of all, to study the experience of countries with developed digital processes, change it depending on the characteristics of our economy, and also determine the current state of this process in our country.

Digitalization of the national economy brings huge changes in more than 50 different sectors. This phenomenon is related to information technology and platforms are fundamentally changing business models, increasing their results by eliminating them through optimization. Realizing the importance and relevance of the topic the author pursues the following objective: to uncover the essence of the concept of digitalization of the economy; to analyze the process of digitalization the economy in Kazakhstan practice, to consider digital processes in the entities that have entered into economic relations, to identify the features of the digitalization of the economy as a whole to study domestic experience of digitalization of the economy in our country.

Key words: transformation of the information society, digitalization of the economy, digital economy, knowledge economy, world economy, factors of competitiveness, advanced technologies.

\section{3.С. Кенжебаева ${ }^{1 *}$, А.Е. Тойганбаева²}

'NARXOZ Университеті, Қазақстан, Алматы қ.

${ }^{2}$ Абылай хан атындағы Қазақ халықаралық қатынастар және әлем тілдері университеті, Қазақстан, Алматы қ., "e-mail: zere.kenzhebaeva@narhoz.kz

\section{Цифрлық экономика дамудың жаңа теориясы ретінде: Қазақстанда дамудың мүмкіндіктері, қиындықтары және перспективалары}

Мақалада қазіргі уақытта барлық салаларда, соның ішінде әсіресе экономика саласында қолданылатын цифрландыру, экономиканы цифрландыру және цифрлық процестердің бизнеске енуі туралы ұғымдар мен бағыттары қарастырылады. Ақпараттар алмасудың дәстүрлі форматынан инновациялық цифрлық форматқа өту барысында цифрлық процестерді экономика саласына ендірудің өзінің мақсаттары мен міндеттерін қамтиды, соның ішінде ең маңыздылары келесілер болып табылады: мемлекет тұрғындарының өмір сүру сапасын жақсарта түсу, бизнес процестерді жүргізудің нәтижелігін және тиімділігін арттыру, цифрландыру жағдайында ақпараттардың қолжетімділігін және қорғалуын сақтау.

Қазіргі таңда мемлекет тарапынан ұлттық экономиканы цифрландыруға бағытталған көптеген бағдарламалар енгізілуде. Осы бағытта жұмыстар жүргізу барысында цифрлық экономиканың мәнін, мақсаттарын және цифрландырудың бағыттарын нақтылап анықтау қажет. Өз елімізде цифрландыруды тиімді және тезірек енгізу кезінде ең алдымен цифрлық процестері дамыған елдердің тәжірибесін зерттеп, өз экономикамыздың ерекшеліктеріне қарай өзгертіп, сондай-ақ аталған процестің еліміздегі қазіргі қай-күйін анықтаумен қатар жүргізілуі қажет.

Цифрлық экономика 50-ден аса түрлі салаларда үлкен өзгерістерді қамтиды. Бұл феномен ақпараттық технологиялар және платформалармен байланысты, бизнес-модельдерді түбегейлі өзгеріске ұшаратады, яғни оңтайландыру арқылы жойып, нәтижелерін арттырады. Тақырыптың маңыздылы,ғы мен көкейкестілігін түсіне отырып, авторлар келесі мақсатты көздейді: экономиканы цифрландыру түсінігін ашу; қазақстандық тәжірибеде экономиканы цифрландыру үдерісін талдау, экономикалық қарым-қатынасқа түскен субъектілер жұмысындағы 
цифрлық процестерді қарастыру, өз еліміздегі экономиканы цифрландырудың отандық тәжірибесін зерттеу мақсатында жалпы экономиканы цифрландырудың ерекшеліктерін анықтау.

Түйін сөздер: ақпараттық қоғамды трансформациялау, экономиканы цифрландыру, цифрлық экономика, білім экономикасы, әлемдік шаруашылық, бәсекеге қабілеттілік факторлары, озық технологиялар.

\author{
3.С. Кенжебаева ${ }^{1 *}$, А.Е. Тойганбаева ${ }^{2}$ \\ ${ }^{1}$ Университет NARXOZ, Казахстан, г. Алматы \\ ${ }^{2}$ Казахский университет международных отношений и мировых языков имени Абылай хана, Казахстан, г. Алматы \\ *e-mail: zere.kenzhebaeva@narhoz.kz
}

\title{
Цифровая экономика как новая теория развития: вызовы, возможности и перспективы развития в Казахстане
}

\begin{abstract}
В статье рассматриваются понятия и направления цифровизации, цифровизации экономики и проникновение цифровых процессов в ведение бизнеса, которые в настоящее время используются во всех сферах, особенно в сфере экономики.

Переход от традиционного формата информационного обмена к инновационному цифровому включает в себя цели и задачи внедрения цифровых процессов в сферу экономики, важнейшими из которых являются: улучшение качества жизни населения государства, повышение результативности и эффективности ведения бизнес-процессов, сохранение доступности и защищенности информации в условиях цифровизации.

В настоящее время государством внедряется множество программ, направленных на цифровизацию национальной экономики. В ходе работы в данном направлении необходимо конкретизировать сущность, цели и направления цифровизации цифровой экономики. При эффективном и скорейшем внедрении цифровизации в страну необходимо, прежде всего, изучить опыт стран с развитыми цифровыми процессами, изменить его в зависимости от особенностей нашей экономики, а также определить текущее состояние данного процесса в нашей стране. Цифровая экономика несет в себе большие перемены для более чем 50 различных отраслей. Этот феномен связан с информационными технологиями и и платформами, которые коренным образом и меняют бизнес-модели, увеличивая их результаты за счет элиминации посредством оптимизации.

Понимая важность и актуальность темы, автор преследует следующую цель: раскрыть сущность понятия цифровизации экономики; проанализировать процесс цифровизации экономики в казахстанской практике, рассмотреть цифровые процессы в работе субъектов, вступивших в экономические отношения, выявить особенности цифровизации экономики в целом с целью изучения отечественного опыта цифровизации экономики в нашей стране.
\end{abstract}

Ключевые слова: трансформация информационного общества, цифровизация экономики, цифровая экономика, экономика знаний, мировое хозяйство, факторы конкурентоспособности, передовые технологий.

\section{Introduction}

In the era of globalization, economists and politicians note that the process of digitalization will become one of the actively used areas of development of the economy and other industries. A significant number of studies have been devoted to this issue (Babkin, 2018; Golovina, Polyanin, Rudakova, 2017; Vertakova Yu. V., Tolstykh T. O., Shkarupeta E. V., Dmitrieva V. V2017).

The main direction of the global world economy is digitalization of all aspects of economic activity, as well as public life.

The significance and relevance of digitalization of subjects of economic relations is determined by the following distinctive features of the development of the current economy

- in the production and distribution of these products, it has become possible to use economies of scale through the use of IT technologies under the influence of modern integration of economic communication systems.

- using the opportunities provided by technologies under the influence of the development of information technologies has reduced time and financial costs both in the economy and in the work of the company;

- Information technologies that standardize and automate the work processes of individual manufacturers and unify the current tasks of manufacturers contribute to the solution of individual production tasks. Thus, it allows to scale the results caused by the use of IT technologies;

- increased competition in economic and market relations increases the economic efficiency of organizations in all sectors of their activities, as a result as a result, the organization, the firm can maintain its competitiveness in the market.

The main direction of the global market is global market is the transition from the knowledge 
economy to the digital economy. What does the transformation of the information society into a digital one mean? This process, of course, is associated with the processes of globalization and integration, the growth of which identifies new trends in the development of the world and sets new standards for economic development.

The world economy consists of important ingrained factors of competitiveness (such as natural resources) are disappearing, and such factors as the level and dynamics of develop new ones advanced technologies, the point of human capital development process and stages of development of digital infrastructure deserve increasing importance. As a result, it can be concluded that the global competitiveness of the economy is determined by the level and dynamics the development of information and communication technologies (hereinafter - ICT) and the speed of their implementation in all spheres of public life, which forms the so-called digital economy.

One of the main goals of this article is to solve the problems of digitalization development in the domestic economy. When forming the the development concept's of the national digital economy and the development of its structure, a clear knowledge of the definition and meaning of the digital economy and the factors shaping it in the future that determine its development is necessary. Also the development of national economy digital economy is possible due to the borrowing and adaptation of foreign experience.

Literature review. The digital economy creates new opportunities for economic development, but at the same time creates new risks and threats. For example, the expansion of the range and individualization of digital entails an increase in number of unauthorized transactions with financial consequences, including transfers of funds, by persons who do not have the appropriate rights, in addition, ethical risks increase - the risks of leakage of confidential information. ... It is necessary to find a balance between supporting technological innovations and the need to protect society from possible risks associated with their implementation.

Economic science identifies the main stages of human development: agrarian, from an industrial point of view industrial, post-industrial and most recent modern digital. The transition of human development from one stage to another is associated with the development of resources and technologies, as well as with a change in culture in society, a change in the political system.

To understand the procedure of development of the information society into a digital one, the knowledge of the concept is important the definition of "digital economy". The founder of this concept is Nicholas Negroponte (1995).

The definition of computer science is given by many scientists, including an American scientific figure in the field of activity computer science gives the definition as: "moving from the movement of atoms to the movement of bits (Negroponte N, 1995).

It is necessary to emphasize that there is still no single term. So, along with the explanation of words, such us "digital economy ", "electronic economy", "new technological order of the world", "creative economy", "API economy", etc. are often used.

At that time, it should be noted that the European scientific community in many cases uses the term "digital economy". In turn, the American one predisposed closer to the technological definition of "API economy".

Therefore, at present, the concept of "digital economy" is not fully fixed. In the structure of the concept, we can include the following concepts and basics, as a high-quality process of a technological nature, are software, information and computer technologies. Together with the above concepts, we can include existing Internet programs. These include: services provided on the internet, internet services and messengers.

Since the digital economy, which has become a global trend, has just arrived in Kazakhstan, this direction is gradually developing on our territory. A new priority for the country's economic development is the transition from traditional information exchange in all sectors of the economy to digital.

There are many technologies (cognitive, cloud, Internet of things, big data, etc.) that will actually affect our lives directly in the future. One of the main factors in the development of the international economy is the active participation of digitalization in our life and economy.

According to the given information, McKinsey Global Institute, in China, up to $22 \%$ of the increase in GDP by 2025 may be due to Internet technology. In the United States, the expected increase in value from digital technologies is equally impressive - here it could reach $\$ 1.6-2.2$ trillion by 2025 . (Tarasov I. V., 2018).

Consider the views of individual authors on the digital economy category. So, for example, Yudina T.N. believes that "this concept is associated with the intensive development of information and communication technologies (ICT), the beginning of the second generation informatization process, which is the basis of the emerging VI technological order. In fact, all spheres of human life (economic, 
political, cultural, and social and others) have changed to one degree or another due to the discovery and development of ICT. More and more industries and sectors of the national economy - finance, trade, mechanical engineering, agriculture, construction, transport, communications, medicine, education, etc. - are included in the electronic and digital economy" (Yudina T. N. 2016.). Based on the author's research, in the world economy and in general, digital technologies lead to optimal improvement of technical, economic and economic paradigms. It should be noted that its influence covers all spheres of life.

Authors Evtyanova D.V. and Tiranova M. the. digital economy is explanation such as "automated management of the economy based on advanced information technologies; way, based on effective information management of the production system " (Evtyanova D.V., Tiranova M.V., 2017).

In this definition, the authors came to the following conclusions: the main component of the modern information economy is the high level of existing technologies that rebuild relations between economic entities. This changes the development paradigm in the direction of applying flexible economic organization schemes, i.e. formulates coordination using digital technologies.

Author N. Vasilenko in the article "Digital economy, concept and reality" noted the main components of the digital economy:

- hardware, software, communication transmission devices, and other infrastructure components;

- interconnection and relationships between entities using virtual networks include electronic business transactions carried out through computer networks;

- the biggest part of the digital economy that has become a modern trend is e-Commerce, which in turn involves selling and delivering goods over the Internet.

Thus, in the course of development and improvement of this area of the digital economy, must provide it with an accompanying infrastructure, which explains the provision of the economy with effective software products and network structures of the Internet.

One of the new concepts emerging from this is infoculture, this term explains the integration of information technologies into people's lives. One of its features is that it includes everyday habits and customs. All these characteristics are considered in the research paper "Digital future or the economy of happiness". (Chernovalov A., Tsekanovsky., Shimansky Z., and others, 2018).

Materials and methods. The methodological basis is a review of scientific works on the topic of digitalization of the national economy. Additionally, in this article general scientific methods of cognition were used, in particular: analysis and synthesis.

Results and discussion. Economy our county today, humanity is faced with a whole galaxy of different kinds of challenges: a decrease in the share of employed in industrial production in developed countries, the transition to an economy of action, a change in educational models, personalization and flexibility of production, the increasing role of networking, the rapid growth of firms investing in capital, based on knowledge and included in global value chains.

The existing galaxy of global challenges largely determines not only how the economy will develop, but also what our society will be like. Here, the socalled "digital economy" comes to thefore, that is, an economy based on data, an economy that is a cardinal breakdown of traditional economic models. The formation and development of the digital economy is largely based on a whole class of completely new technologies based on cyber-physical principles, that is, on the junction of the physical world and the virtual world.

In modern conditions, in various countries of the world economy, the strategies "Industry 4.0", "Internet +" are being implemented. For example, in 2010 the European Union adopted the Digital Europe initiative aimed at shaping the Internet economy. In 2011, a developed country like Germany initiated a strategic program for Industry 4.0, proclaiming the transition to "Internet-based manufacturing". In China, in 2015, the Internet + concept was adopted, which is based on "smart manufacturing". The goal of creating "smart" industrial production was also reflected in the "Cloud Strategy" initiative, adopted in 2009 in the United States. (Moavenzadeh J., 2015).

An international organization like the UN is developing a world-wide rating for ICT development-the ICT Development Index, which is calculated under the guidance of the UN. Since 2015, our country has been ranked 52 out of 175 positions. Thus, our country has set a goal in which it plans to reach the 30th place in 2020, the 25th place in 2025 and the 15 th place closer to 2050 .

Economy our country today inferior in this rating to the majority of developed countries and countries with fast growing economies. Undoubtedly, this situation does not create real opportunities for successful competition on a global market innovative technologies and explains the lag of Kazakhstan quality of life of the country's citizens in comparison with developed countries.

In the digital technology market, which to a certain extent is distinguished by its "depersonalization", 
economy and transparency, virtuality acquires a huge multiplicative effect and becomes a real productive force.

The novelty of the phenomena occurring with new digital technologies, as well as the distinctive features of information technologies cardinal changes in the psychological perception of people and their consumers now require resource support for special ways to form of new thinking, methods of education and technological renewal.

Currently, around the concept of the digital economy, scientific interest in the study of socioeconomic effects of the introduction of digital technologies in scientific circles has increased. This interest is largely related to the development of proposals to accelerate the process of integration of States into a large global network with minimal risks to the economy, politics, and society.

In the scientific field, one of the main interests of researchers in the humanitarian field is characterized by the penetration of digitalization into our life community and social environment. (Sivukha, 2012).

One of the new programs introduced by the state "Digital Kazakhstan", unlike others - the program is aimed at spreading digitalization covering all sectors of the economy, development and development of new innovative technologies, improving the quality of life of citizens.

The main and main aspiration is programme is increase the pace of development in priority and main areas of the economy for a period of time in the medium term and work to improve and further develop the quality of life of the population, and in the long- term development of Kazakhstan's economy in a new direction will be achieved with the integration and development of digital technology on the market."

Columbia University professor Raul Katz identifies 3 waves of digital technology development. The first stage is characterized by total computerization and automation of processes, the spread of mobile communications, as well as the development of wired and wireless broadband Internet access. The features of the second wave are the development of online platforms (such as search engines, marketplaces, distance learning, social networks) and cloud computing. The third wave is predictive Analytics of big data, as well as the Internet of things, robotics, and new high-tech technologies. 5 (including 3D printing), artificial intelligence (including machine learning) (Katz $\mathrm{R}$, 2017). Social and economic impact of digital transformation on the economy (ITU, GSR-17 Discussion paper, 2017).
These waves of technological innovation successively replace each other, coexisting for a while in the same time period. In Kazakhstan, work is being implemented to overcome technological gaps in the digital economy.

Thus, the nationwide program "Digital Kazakhstan" was approved by the Decision of the Government of our country No. 827 dated December 12, 2017.

Now all States have entered the era of information technology, which has changed rapidly and radically. The industrial Internet of things, artificial intelligence, blockchain, virtual and advanced technologies began to penetrate deeply into the life of mankind. Through the process of digitalization, the economy of States develops and becomes competitive. Most developed countries at this time in the current situation many countries around the world want digitalization to spread in all sectors of the economy by implementing digitalization programs. An example of this is Singapore, which reflects the transformation of the state's digital economy. According to the plan, $50 \%$ of all modes of transport in this country will be electric by 2050 . Today, selfdriving taxis are already used in Singapore. (Rashid K., 2018.)

Our country is dynamically participating in developing a program on the digital agenda within the framework of the EAEU. Heads of state of this organization plan to implement the digitalization process until 2050. There are about 340 front offices throughout the country that make up the state Corporation "Government for citizens". This program provides more than 38 million services to citizens every year. In order to increase the accessibility of remote localities for citizens of our country, 70 mobile PSCs are engaged in providing services each year, which make more than 12 thousand calls. they provide more than 500 thousand services. Under this program, established and operational list for the provision of public services, the hallmark of this program is the point that it runs constantly. Today, with the help of this program, citizens of our country can apply for and receive 746 public services.

The use and introduction of technologies such as Big Data, it will help we expand the list of services provided.

In addition, such technologies fully form the information technology base. The concept of the digital economy is based on analytical systems and programs that contain large and large amounts of data (Big Data). Since such programs have a growing volume of modern data, and the same data is characterized by a not particularly structured format. 
In this regard, the provision of public services through such technologies is effective. With the help of them, we can study the tendencies of political views depending on the gender, age or profession of a person. (Gribanov Yu. I., Repin N. V., 2017). In addition, big data systems can be used in trade, finance, real estate rental, and national security.

As part of the new program for the development of digitalization in Kazakhstan, the state program "Digital Kazakhstan" has been created and operates since this year.

The main goals of this program are aimed at improving degree and standard of living of citizens through integration and exploitation digital technologies.

Development and execution of the program "Digital Kazakhstan" focuses on five most important aspects. Let's get acquainted with these directions in more detail. Under this program, the key sectors of our economy for implementing the digitalization process are considered to be: industry, logistics, transport, electricity, agro-based industries.

Evaluation of the implementation of the Industry 4.0 program in these sectors was carried out with the help of foreign experts. The greatest attention was also paid to the modernization of processing and mining industries.

One of the following directions is the direction "transition to a digital state", the content of which is the smooth exchange of public services for the population and business of the country through online networks, ensuring the security of information, the availability of existing technologies, and the availability of reliable information.

The technology for providing e-health passport services has been launched since June this year. Electronic journals and diaries have been introduced in the field of education. The system of automatic electronic distribution of children to preschool organizations in 11 cities began at the beginning of this year. The transfer of citizens to register in electronic form will eliminate the issuance of more than 2 million certificates.

The third direction of the program is called "implementation of digitalization of the great silk road", the main goal of which is to provide mobile communications covering the entire territory of the state, and to ensure high-speed and stable operation of the network without any interruptions in Internet access. As a result of the implementation of this direction in 1249 rural localities, measures have been initiated to create the possibility of using permanent, uninterrupted global Internet networks.

High-tech laboratories specifically designed to ensure information cybersecurity for Big Data analysis are being developed and implemented, especially increased attention is given to malicious code and cyber incidents. "Human capital development" is the fourth direction of the program, this direction provides improvement of literacy and awareness of digital processes among the population. Implementation will only be possible thanks to the introduction of innovations in education.

Thus, much attention is paid to improving creative and new critical thinking. We can add that now technologies are used for process of retraining all ages of the population: children, youth, students and employees.

Young people are being trained and retrained population is being steadily carried out, with special attention being paid to the unemployed citizens of the country.

"Organization of the innovation ecosystem" is the fifth direction and is aimed at further development of technological entrepreneurship with reliable and safe interaction between 3 key elements: business, science and the state. Closer to 2022, it is planned to create a large number of domestic technology companies that will have their own "success stories" in this direction.

As a result of the implementation of the Digital Kazakhstan program, it is planned to achieve great results. In particular, by 2025 , the program should bring to the budget 1.7-2.2 trillion tenge, which is planned to be returned on the basis of added value. This amount is also 4.8-6.4 times higher than the invested investment funds. The main goal of work to maximize the introduction of digitalization in our country is that as a result of these processes, the entire country should be digitized and this will ensure a third of the GDP growth of the economy through these measures.

In 2020, performance growth in key sectors of the economy will increase from $20 \%$ to $50 \%$. This program will create 300 thousand new jobs (such as industry $4.0,2016)$. In the UN ICT ranking, our country's goal is to take the 30th place. The implementation of the program's directions should provide $1.6-2.2 \%$ growth points closer to 2025 .

Another of the goals of the program is that in 2022, 5 cities of our country should appear among the smart cities. In order to fully implement the digitalization program, funds will be allocated annually from the budget, including 21.5 billion tenge in 2018, 33.1 billion tenge in 2019, 59.7 billion tenge in 2020, and 26.5 billion tenge in 2021 ( Korolev, 2018).

If we analyze the cost of ICT by country, we get the following information. These include: information technology-5\%, software support 
- 37\%, training workers to work with ICT- $6 \%$, software development processes by organizations themselves-5\%.

If we look at the costs in the context of 1 ICT sector, we will find the following points: trade $31.1 \%$, information and communications $-12.9 \%$, manufacturing $-8.8 \%$. Mining $-8.8 \%$, construction $-8.4 \%$, highly qualified scientific and technical work $-8 \%$, national management and management $-7.2 \%$, logistics and warehouse $-5.6 \%$, agriculture $-0.3 \%$, other sectors $-8.8 \%$.

Using positive results of the digital economy is achieved only if all residents of the country have the skills to use digital technologies. However, currently the population's ability to use new computer technologies is $76.2 \%$. in this case, it is necessary to increase literacy in the near future.

In the current situation, the Ministry of education and science of our country is implementing new initiatives and proposals. (Decree of the Government of the Republic of Kazakhstan, 2017).

1) for the purpose to get acquainted with modern information technologies and training in information technologies, the subject "Information and communication technologies" was introduced for students of grades 3-4 who form general basic knowledge;

2) 372 circles on robotics are working, teaching General principles and basics of programming in the roar of robotics.

In addition, it should be noted that the new requirements and regulations younger generation in accordance with the passage of time, it is planned to rework the content of secondary education by developing their creative thinking and technical skills.

1) in order to develop information technology skills, students have introduced the discipline 'information and communication technologies' in excerpt three specialties;

2) new professional norms and standards are being created, which will become the main basis for educational programs of technical and professional, higher and postgraduate education.

Nevertheless, despite the implementation of such works, there is a small number of information technology specialists in the domestic economy who have the necessary knowledge and skills, professional experience.

The process of digitalization imposes higher requirements on the process of conducting work, including the process of functioning of entrepreneurs that existed in the modern market. The lack of communication and understanding between the employment sector and the workers ' sector can lead to retraining of personnel that the market does not need, and training of unnecessary workers. To prevent this from happening, it is necessary to prepare the population of all ages with digital technologies.

The state program to develop the economy our contry and improvement and developing the quality of life of citizens of the country with the participation of the Samruk-Kazyna Fund is being implemented in all cities of the state.

According to the agreed plan, as a result of the program execution, this project brought more than 2 trillion tenge to the state budget. Digitalization will cover all sectors of our state, which will lead to the following positive changes from the project implementation: reducing costs, having reality in decision-making, stopping corruption, etc.

The efficiency of city and municipal services in Kazakhstan is intended to be achieved through the introduction of digital technologies. The main central element of the Smart City project is the person and their needs.

Plan for half a year, the cities such as, NurSultan and Almaty will fully turn into a "smart city", and in the future, Karaganda, Aktobe, Shymkent will be transformed into a Smart CIty. With the improvement of these cities, new infrastructure will be created, which will improve the quality of life of citizens, safety, environmental cleanliness, and the work of all existing sectors.

This isn 't a domestic invention of our country, this is the experience of advanced countries of the world. The main directions of the Smart City provisions of the regulations are developed depending on the experience of developing cities in European countries and are based on the inter actions of 6 subjects : "smart economy", "smart management", "smart life", "smart mobility", "smart people" and "smart environment". Thanks to the construction and application of this model, European countries and their residents have achieved great success in developing the social and economic environment of the city. Our country has studied the experience of European countries, analyzed foreign experience depending on the characteristics of the society and infrastructure of our country.

We can talk about positive results for a long time, there are a lot of them.

According to the state's plan, the following changes will occur through the digitalization of the economy: saving energy and money in the electricity sector; the main ways to reduce costs in the activities of utility networks, reducing incidents related to crime in society and improving the life of the population as a whole.

According to the plan of the Samruk-Kazyna Foundation for 2022, all cities on the territory of 
our state will be included in the number of "smart cities". Another direction of this program is to Create an innovation ecosystem on the territory of the state and support new startups in the innovation sphere by creating it. One of the main goals of the program is to create maximum conditions for capitalization and revenue generation of these projects. To achieve this goal, the state will invest about 67 billion tenge in startups in 2022. By 2022 , the country plans to increase the volume of investments that will be attracted to startups to 67 billion tenge.

\section{Conclusion}

The introduction and improvement of digitalization in the market will lead to faster economic growth in Kazakhstan compared with the present current positions.

As notes in the addresses of the President Kassym-Jomart Tokayev to the people of Kazakhstan dated September 1, 2020: "Digitalization is not only a trend of the new economics at the present stage, but also, in General, the development and competitiveness of the national economy.»

Basically, in the future it is necessary to eliminate digital inequality, ensure maximum access to the Internet for the population and high-quality and effective communication for all citizens. This is now becoming a basic need, such as electricity and electricity that is used daily.
In order to create new jobs in the labor market within the country, as well as to export digital technologies and provide them to the world market, it is necessary to develop the market for engineering, IT and high - quality technological services in the country's market.

In order to develop the economy, we will have great prospects through the interaction of business and IT technologies. (President of Kazakhstan KassymJomart Tokayev's State of the Nation Address, 2020).

As a result of execution of the integration of civilization into all economic spheres, economic development is accelerating. This can be seen in practice in many developed countries.

The development of the main branches of the digitalization economy, including processing production, transport and logistics related to transportation, agriculture, a new direction of trade-eCommerce, exchange of non-cash funds, application of new technologies in the financial sector, will increase the stability of capital to the rapid payback and cost-effectiveness of implemented projects in the economy.

Thus, we managed to establish that the most important thing in the economy of the future is the digital economy, which is focused on human needs. And if it is focused on a person, will satisfy our needs, help in everyday life, then humanity will have the opportunity to positively develop and special attention is paid to improving life.

\section{References}

The digital economy and industry 4.0: new challenges: proceedings of the scientific and practical conference with international participation (2018) / ed. by A.V. Babkin. SPb.: Publishing house of Polytechnical Institute.UN-TA,. - 573 p.

Golovina, T.A., Polyanin, A.V., Rudakova O.V. (2017). Development of the system of state strategic management of business structures based on the capabilities of the new digital economy model // Bulletin of the Voronezh state University. Series: Economics and management.- No. 2. P. 13-18.

Evtyanova, D.V., Tiranova, M.V. (2017). Digital economy as a mechanism of effective environmental and economic policy // Science. - T. 9. No.6. - https://cyberleninka.ru/article/n/tsifrovaya-ekonomika-kak-mehanizm-effektivnoy-ekologicheskoy-i-ekonomicheskoy-politiki/viewer

Gribanov, Yu.I., Repin, N.V. (2017). Review of the prospects for the application of new methods and management tools in the era of the digital economy. Management development for the transition to a digital economy. Materials of the X All-Russian (with international participation) scientific-practical conference,. - C.33

Holz, Expert (2015). What is Industry 4.0? Figures and facts 08/14/2015. URL: http://holzex.ru/chtotakoe-industriya-4-0-tsifryii-faktyi/ (date of access: 27.11.2016)

Korolev, A. (2018). Digitalization VS Unemployment. November 23, / https://abctv.kz/ru/news/bolshinstvu-predpriyatij-nedostupna-industriya-4-0 18.https: // abctv. kz / en / news / bolshinstvu-predpriyatij-nedostupna-industriya-4-0

Katz, R. (2017). Social and economic impact of digital transformation on the economy. / ITU, GSR-17 Discussion paper. - URL: https://www.itu.int/ en/ITU-D/Conferences/GSR/ Documents/GSR2017/Soc_Eco_impact_Digital_transformation_finalGSR.pdf

Moavenzadeh, J. (2015). The 4th Industrial Revolution: Reshaping the Future of Production. DHL Global Engineering \& Manufacturing Summit. Amsterdam, October 7, 2015. Available at: / https://www.eiseverywhere.com/ file_uploads/fe238270f05e2dbf187e2a60cbcdd68e_2_Keynote_John_Moavenzadeh_World_Economic_Forum.pdf (accessed 11.02.2019).

President of Kazakhstan Kassym-Jomart Tokayev's State of the Nation Address on September 1, 2020 / https: akorda.kz/ru/addresses/addresses_of_president

Negroponte, $\bar{N}$. (1995) Being Digital/- New York -/kupdf.net

Sivukha, S.V. (2012). Social capital / http://bourdieu.name/content/social-capital 
Rashid, K. (2018). Digitalization on the agenda in Kazakhstan 05/03/18/ttps://digitalkz.kz/v-kazahstane-na-povestke-dnja-cifrov/ Tarasov, I.V. (2018). Industry 4.0: concept, concepts, development trends // Business strategy №6 (50). - P.12-16

Vasilenko, N.V. (2017). Digital economy: concepts and reality // Innovation clusters in the digital economy: theory and practice: Proceedings of a scientific and practical conference with international participation. May 17-22 / Ed. A.V. Babkina. SPb. : Publishing house of Polytechnic. un-ta. $-592 \mathrm{~s}$

Vertakova, Yu. V., Tolstykh, T. O., Shkarupeta E. V., Dmitrieva V. V. (2017). Transformation of management systems under the influence of digitalization of the economy: monograph. Kursk: SWSU publishing House, $-156 \mathrm{p}$.

Yudina, T.N. (2016). Understanding the digital economy // Theoretical Economics. -No. 3. - P.12-16

Rashid, K. (2018). Digitalization is on the agenda in Kazakhstan 03.05.18/18 /https://digitalkz.kz/v-kazahstane-na-povestke-dnjacifrov/)

Decree of the Government of the Republic of Kazakhstan (2017). http://adilet.zan.kz/rus/docs/P1700000827) 